\title{
Trophic state of benthic deep-sea ecosystems from two different continental margins off Iberia
}

\author{
A. Dell'Anno ${ }^{1}$, A. Pusceddu ${ }^{1}$, C. Corinaldesi ${ }^{1}$, M. Canals ${ }^{2}$, S. Heussner ${ }^{3}$, L. Thomsen ${ }^{4}$, and R. Danovaro ${ }^{1}$ \\ ${ }^{1}$ Department of Life and Environmental Science, Polytechnic University of Marche, Via Brecce Bianche, 60131 Ancona, Italy \\ ${ }^{2}$ GRC Geociències Marines, Departament d'Estratigrafia, Paleontologia i Geociències Marines, Facultat de Geologia, \\ Universitat de Barcelona, Campus de Pedralbes, Martí i Franquès s/n, 08028 Barcelona, Spain \\ ${ }^{3}$ CEFREM, UMR 5110 CNRS-University of Perpignan, 66860 Perpignan Cedex, France \\ ${ }^{4}$ School of Engineering and Science - SES, Earth and Space Sciences, Jacobs University, Campus Ring 1, 28759 Bremen, \\ Germany
}

Correspondence to: A. Dell’Anno (a.dellanno@univpm.it)

Received: 22 November 2012 - Published in Biogeosciences Discuss.: 12 December 2012

Revised: 3 April 2013 - Accepted: 8 April 2013 - Published: 2 May 2013

\begin{abstract}
The bioavailability of organic matter in benthic deep-sea ecosystems, commonly used to define their trophic state, can greatly influence key ecological processes such as biomass production and nutrient cycling. Here, we assess the trophic state of deep-sea sediments from open slopes and canyons of the Catalan (NW Mediterranean) and Portuguese (NE Atlantic) continental margins, offshore east and west Iberia, respectively, by using a biomimetic approach based on enzymatic digestion of protein and carbohydrate pools. Patterns of sediment trophic state were analyzed in relation to increasing water depth, including repeated samplings over a $3 \mathrm{yr}$ period in the Catalan margin. Two out of the three sampling periods occurred a few months after dense shelf water cascading events. The benthic deep-sea ecosystems investigated in this study were characterized by high amounts of bioavailable organic matter when compared to other deepsea sediments. Bioavailable organic matter and its nutritional value were significantly higher in the Portuguese margin than in the Catalan margin, thus reflecting differences in primary productivity of surface waters reported for the two regions. Similarly, sediments of the Catalan margin were characterized by significantly higher food quantity and quality in spring, when the phytoplankton bloom occurs in surface waters, than in summer and autumn. Differences in the benthic trophic state of canyons against open slopes were more evident in the Portuguese than in the Catalan margin. In both continental margins, bioavailable organic $\mathrm{C}$ concentrations did not vary or increase with increasing water depth. Overall,
\end{abstract}

our findings suggest that the intensity of primary production processes along with the lateral transfer of organic particles, even amplified by episodic events, can have a role in controlling the quantity and distribution of bioavailable organic detritus and its nutritional value along these continental margin ecosystems.

\section{Introduction}

Continental margins play a key role in the carbon budget and nutrient cycling on a global scale (Liu et al., 2010) and represent hot spots of biomass production and biodiversity (Rex et al., 2006; Danovaro et al., 2010; De Leo et al., 2010; McClain and Barry 2010). They can represent either a sink for particulate matter of autochthonous origin (i.e. derived from biological productivity of surface waters and/or exported from the land), or a source of organic material fueling the deep ocean's interior by lateral transport (Buscail and Germain, 1997; Bauer and Druffel 1998; Canals et al., 2006; Sampéré et al., 2008; Sanchez-Vidal et al., 2008; Masson et al., 2010; Pusceddu et al., 2010). Nevertheless, the extent to which such material is transported and distributed downslope is not consistent along latitudinal or longitudinal gradients, nor constant in time, mainly due to differences in hydrodynamic, topographic, climatic and ecological conditions (Liu et al., 2010). From the topography viewpoint, continental margins are characterized by complex successions of open slopes, 
submarine canyons and landslide-affected areas (Weaver et al., 2004), whose relative importance to key ecological processes (e.g. biomass production and nutrient cycling) is, however, poorly known. Therefore, identifying factors influencing the benthic trophic state (in terms of food quantity and quality) at different spatial and temporal scales is crucial for a better understanding of the functioning of continental margin ecosystems.

There is a general consensus that the trophic state of deepsea ecosystems can greatly influence the abundance, biomass and activity of benthic assemblages from micro- to megafauna (Gooday, 2002; Smith et al., 2008; Danovaro et al., 2008a; Bianchelli et al., 2010), with cascade effects on the provisioning of ecosystem's goods and services (Danovaro et al., 2008b). However, assessing the trophic state of benthic deep-sea ecosystems is a difficult task since organic detritus is made of a complex array of compounds exhibiting different levels of bioavailability, i.e. from highly labile to refractory compounds (Mayer 1995; Middelburg et al., 1999; Dell' Anno et al., 2000; Dell' Anno and Danovaro 2005; Middelburg and Meysman 2007; Pusceddu et al., 2009). This limits the use of total organic $\mathrm{C}$ and $\mathrm{N}$ pools as suitable quantitative descriptors of food availability for consumers (Dell'Anno et al., 2002; Pusceddu et al., 2009), especially for sediments in continental margins receiving large inputs of land-derived organic material, which is potentially more recalcitrant to biodegradation than organic compounds of marine origin (Wakeham and Canuel, 2006; Sanchez-Garcia et al., 2009). To overcome this problem, some authors have estimated the labile fraction of organic matter in deep-sea sediments through the determination of the main biochemical classes of organic compounds (i.e. total carbohydrates, proteins and lipids), which are assumed to be easier to digest and assimilate by benthic consumers (Tselepides et al., 2000; Danovaro et al., 2003; Pusceddu et al., 2010). However, this approach has some limitations, as the analysis of total carbohydrate, for instance, does not discriminate between highly refractory structural components and easily degradable compounds (Buscail et al. 1995; Dell'Anno et al., 2000; Pusceddu et al., 2003). An alternative approach, based on an enzymatic hydrolysis of sediment samples carried out in the laboratory (i.e. biomimetic approach, sensu Mayer et al., 1995), has been proposed for mimicking organic matter degradation steps in deposit feeding (George, 1964; Mayer et al., 1995; Dauwe et al., 1999a). The enzymatically hydrolyzed organic matter pools represent a reliable estimate of the food availability for heterotrophic consumers, thus providing insights on benthic trophodynamics (Dauwe et al., 1999b; Dell'Anno et al. 2000; Pusceddu et al., 2003; Grémare et al., 2005; Mayer et al., 2008; Bourgeois et al., 2011).

Here, using a biomimetic approach, we investigated the bioavailability of organic detritus and its nutritional value in surface deep-sea sediments from open slopes and canyons of the Catalan (NW Mediterranean) and Portuguese (NE At- lantic) continental margins. Topographic differences within the same area (slope vs. canyon) along with differences in primary productivity and hydrodynamic characteristics of the two continental margins are expected to influence the magnitude and distribution of particle supply to the deep-sea floor, thus providing new insights on factors controlling food availability in benthic deep-sea ecosystems.

\section{Materials and methods}

\subsection{Study areas and sampling strategy}

Sediment samples were collected along the Catalan margin in May 2004, October 2005 and August 2006 at ca. 1000 and $1900 \mathrm{~m}$ depth and along the Portuguese margin in September 2006 at depths of between ca. 400 and $4200 \mathrm{~m}$ (Fig. 1, Table S1). At all stations triplicate sediment samples were retrieved from three independent deployments of a multicorer. Each sediment core was sliced vertically and the top $1 \mathrm{~cm}$ stored in Petri dishes at $-20^{\circ} \mathrm{C}$ until biochemical analyses. Although the inventory can locally provide estimates of the actual organic matter contents in the sediment that are different from estimates obtained solely from the top surface of the sediment core, it has been demonstrated that the analysis of the top $1 \mathrm{~cm}$ represents a proxy of the whole trophic state of marine sediments (Pusceddu et al., 2009).

In the Catalan margin, sediments were collected at four stations, two of which within Cap de Creus canyon and the others in the adjacent open slope at similar depths. Cap de Creus canyon is located in the westernmost part of the Gulf of Lion, where the shelf narrows and where the wind driven coastal circulation and the Liguro-Provençal or Northern Current converge (Millot, 1990). The head of Cap de Creus canyon is $12 \mathrm{~km}$ from the coastline and the canyon extends for $95 \mathrm{~km}$ basinwards till entering the deeper Sete canyon at about $2150 \mathrm{~m}$ depth. Recent studies conducted on the Catalan margin reported that Cap de Creus canyon represents a preferential pathway of particle transport for the entire Gulf of Lion (Palanques et al., 2006) and that dense shelf water cascading (DSWC) events occurring during winter periods represent one of the main mechanisms of sediment export towards deeper waters (Canals et al., 2006; Sanchez-Vidal et al., 2008; Palanques et al., 2012). Two major DSWC events occurred in winter/early spring 2005 and 2006, a few months before the sediment sampling in October 2005 and August 2006. These events, driven by exceptionally strong, dry northern winds, spread down to the Catalan margin with maximum near-bottom current velocities of ca. $1 \mathrm{~m} \mathrm{~s}^{-1}$ (Canals et al., 2006; Palanques et al., 2012) conveying large amounts of organic material into Cap de Creus canyon and the adjacent southern open slope (Canals et al., 2006; Sanchez-Vidal et al., 2008, 2009; Pasqual et al., 2010). Primary production in the Gulf of Lion ranges between 78 and $142 \mathrm{~g} \mathrm{C} \mathrm{m}^{-2} \mathrm{yr}^{-1}$ (Lefevre et al., 1997). 


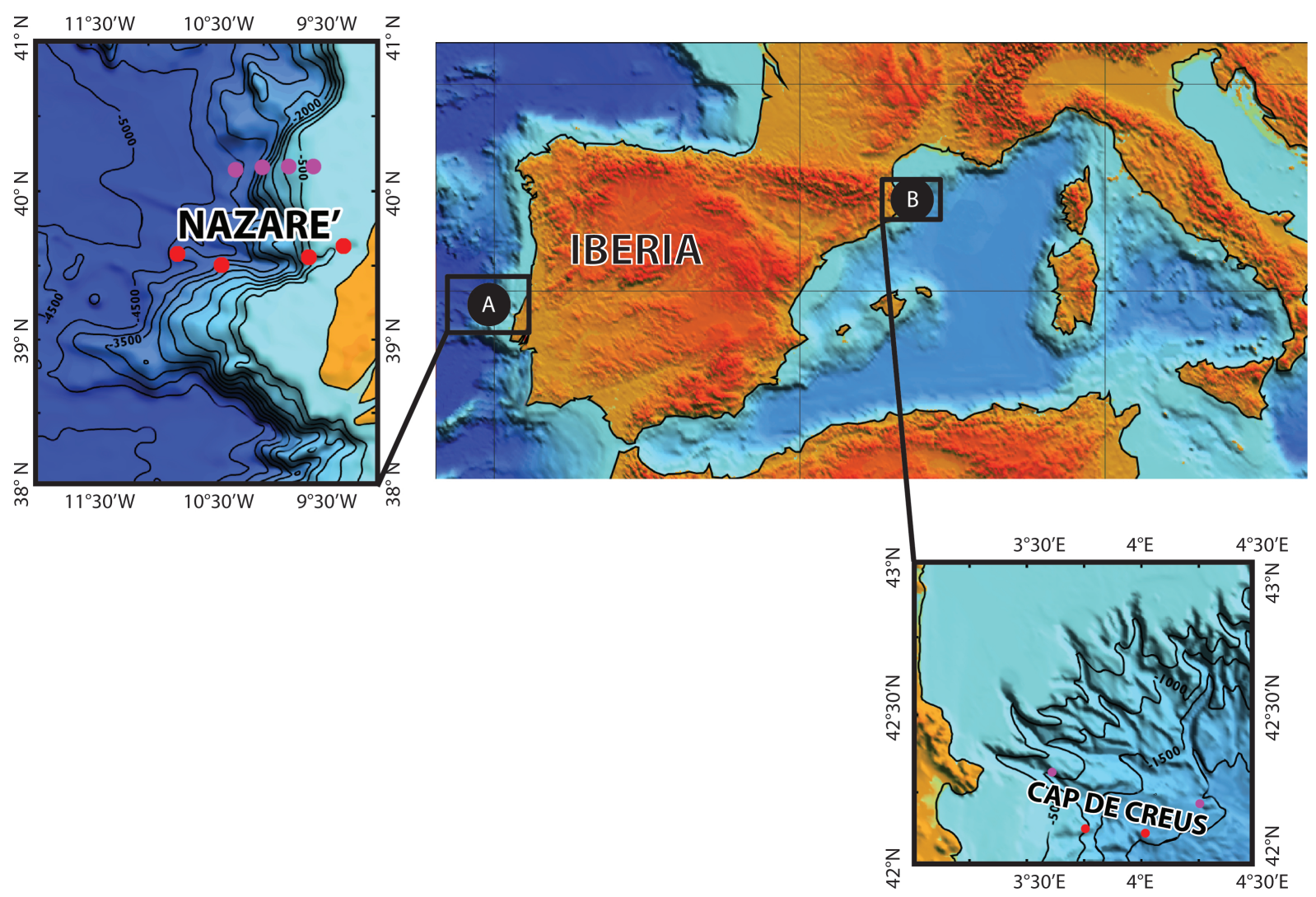

Fig. 1. Study area and sampling locations in the Portuguese (A) and Catalan (B) margins, offshore west and east Iberia, respectively.

In the Portuguese margin, sediments were collected at eight stations, four of which located within the Nazarè canyon and four in the adjacent open slope area. The continental shelf of the Portuguese margin is relatively narrow, with the offshore limit (corresponding to the isobath of $200 \mathrm{~m}$ ) located $15-30 \mathrm{~km}$ from the coastline. The Nazarè canyon, located in the middle part of this margin, is the largest canyon in the area, and intersects the entire continental shelf. The upper and middle canyon collect particles resuspended and transported from the upper shelf and adjacent slope (de Stigter et al., 2007). Intermittent sediment gravity flows have been registered in the canyon which, coupled to the internal tide circulation, produce a net downward canyon transport of particulate material (de Stigter et al., 2007). Although this canyon is not connected to a river, it acts as a major sediment sink (Arzola et al., 2008). The bulk of the organic matter in the Nazarè sediments is mainly derived from terrestrial sources, largely due to the alongshore transport of terrigenous material rather than vertical deposition of material from the euphotic zone (Epping et al., 2002; Kiriakoulakis et al., 2011). The total organic carbon inputs to deep-sea sediments of the Nazarè canyon vary from ca. 5 to $41 \mathrm{gC} \mathrm{m}^{-2} \mathrm{yr}^{-1}$ (at ca. 4300 and $340 \mathrm{~m}$ depth, respectively; Epping et al., 2002); and two contrasting environments, based on the analyses of the near-bottom particle dynamics, have been recently identified in the the upper and middle section of the canyon (Martìn et al., 2011). The upper section of the canyon at $1600 \mathrm{~m}$ depth is characterized by high current speeds (with spring tides 20 up to $80 \mathrm{~cm} \mathrm{~s}^{-1}$ ) and high mass fluxes of particulate matter (up to $265 \mathrm{~g} \mathrm{~m}^{-2} \mathrm{~d}^{-1}$ ), while the middle section at $3300 \mathrm{~m}$ depth is characterized by mass fluxes below $10 \mathrm{~g} \mathrm{~m}^{-2} \mathrm{~d}^{-1}$.

Primary production values of surface waters in the Portuguese margin vary between 154 and $556 \mathrm{~g} \mathrm{C} \mathrm{m}^{-2} \mathrm{yr}^{-1}$ (Alvarez-Salgado et al., 2003). Such higher values of primary production compared to the Gulf of Lion are the result of the prevailing summer upwelling regime characterizing the Portuguese margin (Vitorino et al., 2002). This was also confirmed by values of net photosynthetic primary production extracted from the ocean productivity database (http://www.science.oregonstate.edu) for the same sediment sampling locations and periods. Values of primary productivity of September 2006 in the Portuguese margin were, indeed, ca. 2-fold higher than those of August 2006 in the Catalan margin (on average $1632 \pm 212 \mathrm{mg} \mathrm{C} \mathrm{m}^{-2} \mathrm{~d}^{-1}$ vs. $\left.743 \pm 26 \mathrm{mg} \mathrm{C} \mathrm{m}^{-2} \mathrm{~d}^{-1}\right)$. 


\subsection{Phytopigments and sediment organic matter composition}

Chloroplastic pigments (chlorophyll $a$ and phaeopigments) were analyzed fluorometrically according to Lorenzen and Jeffrey (1980). Pigments were extracted with $90 \%$ acetone $\left(12 \mathrm{~h}\right.$ in the dark at $\left.4{ }^{\circ} \mathrm{C}\right)$. After centrifugation, the supernatant was used to determine the functional chlorophyll $a$ and acidified with $0.1 \mathrm{~N} \mathrm{HCl}$ in order to estimate phaeopigments. Total phytopigment concentrations (CPE) were defined as the sum of chlorophyll $a$ and phaeopigment concentrations (Thiel, 1978).

Total protein (TPRT), carbohydrate (TCHO) and lipid (TLIP) concentrations in the sediment were determined spectrophotometrically, as described in detail by Danovaro (2010), and concentrations were expressed as bovine serum albumin, glucose and tripalmitine equivalents, respectively. For each biochemical assay, blanks were obtained using pre-combusted sediments $\left(450{ }^{\circ} \mathrm{C}\right.$ for $\left.4 \mathrm{~h}\right)$. For all of the stations, all analyses were performed on triplicate sediment subsamples (about $0.5-1 \mathrm{~g}$ ). Carbohydrate, protein and lipid sediment contents were converted into carbon equivalents using the conversion factors of $0.40,0.49$ and $0.75 \mathrm{mg} \mathrm{C} \mathrm{mg}^{-1}$, respectively, and their sum defined as the biopolymeric organic carbon (sensu Fabiano et al., 1995).

\subsection{Bioavailability and nutritional value of organic matter in the sediments}

A biomimetic approach, based on enzymatic hydrolysis of organic matter, was used to determine the bioavailable fraction of the total protein and carbohydrate pools in the sediment. Proteins and carbohydrates were selected because they represent the dominant biochemical classes of organic compounds in benthic marine systems worldwide and thus are expected to be the main potential food sources for heterothophic metabolism (Pusceddu et al., 2009). Enzymatically hydrolysable protein and carbohydrate pools in the sediment were determined according to Dell'Anno et al. (2000) with slight modifications. For enzymatic digestion of sedimentary protein pools, frozen sediment samples were homogenized in TRIS-HCl 0,1 M, EDTA 0,1 M buffer (pH 7.5, buffer : sediment ratio of 2.5 volume weight $^{-1}$ ) and the resulting slurry sonicated three times for $1 \mathrm{~min}$ (with intervals of $30 \mathrm{~s}$ every minute). Triplicate subsamples of the slurry (treated samples) were added to $100 \mu \mathrm{L}$ of proteinase $\mathrm{K}$ $\left(1 \mathrm{mg} \mathrm{mL}^{-1}\right)$ and $100 \mu \mathrm{L}$ of protease $\left(600 \mu \mathrm{g} \mathrm{mL}^{-1}\right)$ solutions. An equal volume of TRIS- $\mathrm{HCl} 0,1 \mathrm{M}$, EDTA $0,1 \mathrm{M}$ buffer solution without enzymes (control samples) was added to another set of triplicate sediment subsamples. All samples were incubated for $2 \mathrm{~h}$ at room temperature under gentle agitation. Incubation time was selected after checking the highest amount of proteins released enzymatically through time-course experiments carried out on additional sediment subsamples. After incubation, samples were cen- trifuged $(10000 \times \mathrm{g}$ for $10 \mathrm{~min}$.) and the sediments rinsed twice with $5 \mathrm{~mL}$ of MilliQ water to remove the digested proteins and the enzymes. Sediment subsamples, pre-combusted in a muffle furnace at $450^{\circ} \mathrm{C}$ for $4 \mathrm{~h}$ and processed as describe above, were utilized as blanks. Protein analyses from these samples were then carried out according to the procedure described by Danovaro (2010). Differences between protein concentrations of control and treated samples were assumed to account for the proteins actually hydrolyzed by proteases (i.e. enzymatically digestible). Enzymatically hydrolyzed protein concentrations (HPRT) were normalized to sediment dry weight.

For enzymatic digestion of sedimentary carbohydrate pools, frozen sediment samples were homogenized with 0.1 M Na-Phosphate, 0.1 M EDTA (pH 6.9; sediment:buffer ratio of 2.5 weight volume ${ }^{-1}$ ) and sonicated three times for $1 \mathrm{~min}$ (with intervals of $30 \mathrm{~s}$ ). Replicates samples of the slurry ( $n=3$, treated samples) were added to $100 \mu \mathrm{L}$ of $\alpha$ amylase, $50 \mu \mathrm{L}$ of $\beta$-glucosidase, $100 \mu \mathrm{L}$ of proteinase-K and $100 \mu \mathrm{L}$ of lipase (stock solution of all enzymes was $1 \mathrm{mg} \mathrm{mL}^{-1}$ ). Another set of replicates treated adding $0.1 \mathrm{M}$ Na-Phosphate instead of enzyme solutions was utilized as control. Samples were incubated for $2 \mathrm{~h}$ at room temperature (after checking the highest amount of carbohydrates released enzymatically through time-course experiments) under gentle agitation. As for protein hydrolysis, sediment subsamples, pre-combusted at $450^{\circ} \mathrm{C}$ for $4 \mathrm{~h}$ and processed as describe above were utilized as blanks. After incubation, all samples were centrifuged (at $10000 \times \mathrm{g}$ for $10 \mathrm{~min}$ ) and an aliquot of the supernatant was utilized to determine carbohydrates released from the sediments. Soluble carbohydrates were determined from the supernatant of the control sample. Carbohydrates from all supernatants and from intact sediments were analyzed spectrophotometrically according to Danovaro (2010). The actual fraction of hydrolyzed carbohydrates was obtained by difference between the carbohydrate concentrations determined in the supernatant of samples containing enzymes and the soluble fraction of the control. Enzymatically hydrolysable carbohydrate concentrations (HCHO) were normalized to sediment dry weight.

Bioavailable organic carbon (BAOC, sensu Danovaro et al., 2001a) was defined as the sum of the carbon equivalents of enzymatically hydrolysable protein and carbohydrate pools.

The nutritional value of organic matter in the sediment was defined on the basis of (i) the contribution of enzymatically digestible proteins to the BAOC pools since proteins contain essential elements (i.e. nitrogen) and compounds (i.e. aminoacids) for heterotrophic metabolism (Mayer et. al., 1995; Dell' Anno et al., 2000), and (ii) the relative importance of enzymatically digestible organic matter fractions to their total pools (Danovaro et al., 2001a). 

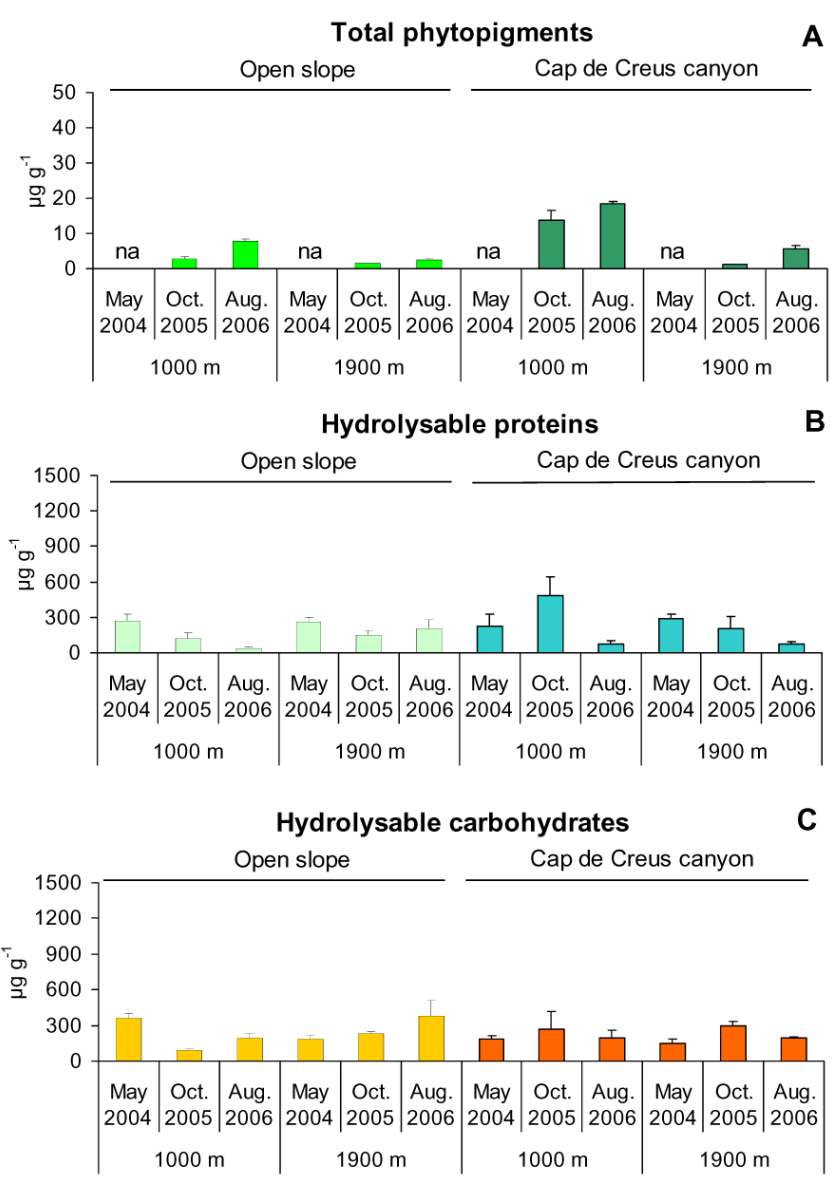

Fig. 2. Spatial distribution of (A) total phytopigment concentrations, (B) enzymatically hydrolysable protein and (C) carbohydrate pools in surface sediments of the Cap de Creus canyon and adjacent open slope of the Catalan margin collected in the different sampling periods. na $=$ not available. Standard deviations are reported.

\subsection{Statistical analyses}

To test for differences in the quantity of bioavailable organic matter (in terms of HPRT, HCHO and BAOC concentrations) and its nutritional value (as the contribution of enzymatically digestible proteins to the BAOC pools and the relative importance of enzymatically digestible organic matter fractions to their total pools) between canyon and open slope sediments of the Catalan margin in different years and at different depths, univariate 3-way analyses of variance (ANOVA) were carried out. The design included three factors: time ( $T$, with 3 fixed levels: May 2004, October 2005, August 2006), environment ( 2 fixed levels, canyon vs. open slope) and depth (2 fixed levels, 1000 vs. $1900 \mathrm{~m}$ depth).

To test for differences between canyon and open slope sediments in the Portuguese margin at different depths, univariate 2-way analyses of variance (ANOVA) were carried out. The design included two factors: environment (2 fixed lev- els, canyon vs. open slope) and depth (4 fixed levels, 400, 960, 3200 and $4200 \mathrm{~m}$ ).

To test for differences between open slopes and canyons of the Catalan and Portuguese margins at similar depths (ca. $1000 \mathrm{~m}$ ), a one-way ANOVA was carried out. To take into account the effect of sampling time, the analysis was restricted only to sediment samples collected almost synoptically (August 2006 and September 2006 in the Catalan and Portuguese margins, respectively).

Before the ANOVAs, the homogeneity of variances was checked using the Cochran's test on appropriately transformed data, whenever necessary. For those data sets that the transformation did not allow for obtaining homogeneous variances, a more conservative level of significance was considered (i.e. $p<0.01$; Underwood, 1997). When significant differences were encountered, a post hoc comparison test (at $\alpha=0.05$ ) was also carried out. All ANOVA and post hoc tests were carried out using the PERMANOVA routine included in the Primer 6+ software package (Anderson et al., 2008).

\section{Results}

\subsection{Bioavailability of organic matter in sediments of the Catalan margin}

In surface sediments of the Catalan margin, total phytopigment concentrations, here used as a proxy of the input of primary organic matter, were characterized by significant temporal changes, with values significantly lower in October 2005 than in August 2006 (up to $18.4 \pm 0.6 \mu \mathrm{g} \mathrm{g}^{-1}$ at $1000 \mathrm{~m}$ depth in Cap de Creus canyon; Fig. 2a, Table S2). Sediments collected in Cap de Creus canyon at $1000 \mathrm{~m}$ depth displayed phytopigment contents significantly higher when compared to those of the adjacent open slope at similar depths. In the different sampling periods, total phytopigment concentrations in surface sediments decreased significantly with increasing water depth. Enzymatically hydrolysable protein (HPRT) and carbohydrate (HCHO) concentrations in surface sediments of the Catalan margin are shown in Fig. 2b-c. HPRT concentrations ranged from $33 \pm 1$ to $268 \pm 33 \mu \mathrm{g} \mathrm{g}^{-1}$ in open slope sediments, and from $74 \pm 28$ to $482 \pm 158 \mu \mathrm{g} \mathrm{g}^{-1}$ in Cap de Creus canyon sediments. The three-way ANOVA revealed a significant effect of the interaction time $\times$ environment $\times$ depth on HPRT pools (Table S2). Thus, the post hoc test revealed that HPRT concentrations were significantly higher in sediments collected in May 2004 than in all other sampling periods, with the exception of samples collected within the canyon at $1000 \mathrm{~m}$ depth. No significant differences in HPRT concentrations were generally observed between sediments of Cap de Creus canyon and those in the adjacent open slope (Table S2).

$\mathrm{HCHO}$ concentrations in open slope sediments ranged from $90 \pm 10$ to $361 \pm 38 \mu \mathrm{g} \mathrm{g}^{-1}$ and from $148 \pm 39$ to 

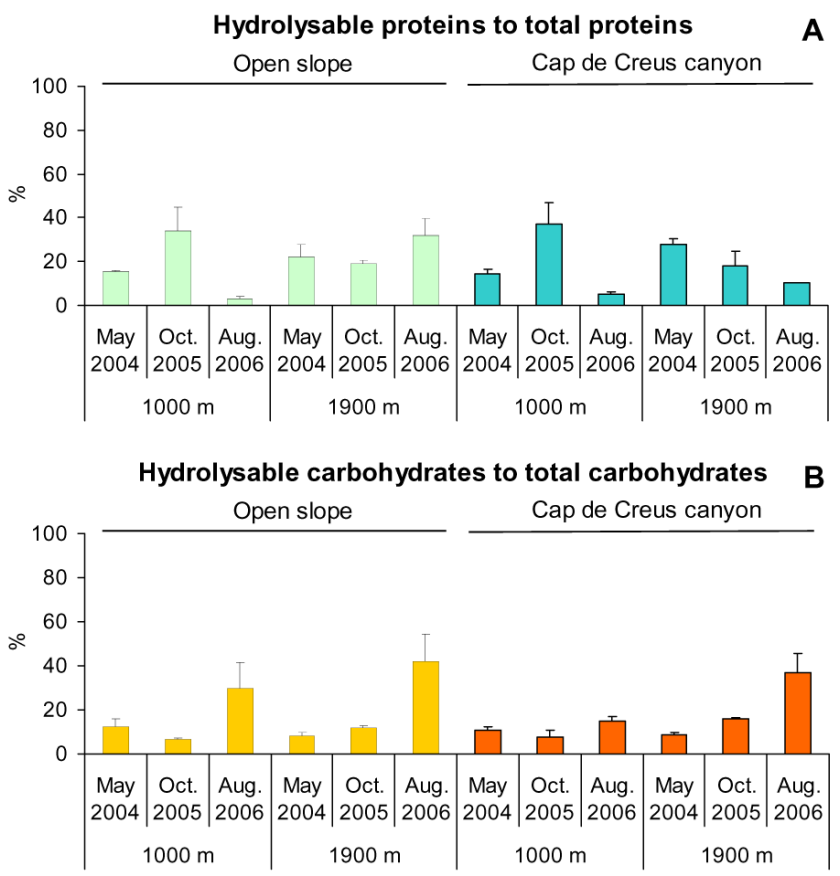

Fig. 3. Spatial patterns of the contribution of (A) enzymatically hydrolysable proteins and (B) carbohydrates to their respective total pools in surface sediments of the Cap de Creus canyon and adjacent open slope of the Catalan margin collected in the different sampling periods. Standard deviations are reported.

$297 \pm 39 \mu \mathrm{gg}^{-1}$ in Cap de Creus canyon sediments. The three-way ANOVA revealed a significant effect of the interaction time $\times$ environment $\times$ depth (Table S2). In October $2005 \mathrm{HCHO}$ concentrations in open slope sediments were significantly higher at $1900 \mathrm{~m}$ depth than at $1000 \mathrm{~m}$ depth, and vice versa in May 2004. No significant differences were observed between the two environments investigated, except in May 2004 at $1000 \mathrm{~m}$ depth, where $\mathrm{HCHO}$ concentrations were significantly higher in open slope than in canyon sediments (Table S2).

The contribution of enzymatically hydrolysable proteins to the total protein pools varied from $3 \pm 1$ to $37 \pm 10 \%$, whereas enzymatically hydrolysable carbohydrates accounted for $7 \pm 0.2$ to $42 \pm 12 \%$ of the total carbohydrate pools (Fig. 3a-b; data on total protein and carbohydrate concentrations are reported in Table S3 of the supplementary material). The contribution of enzymatically hydrolysable proteins to the total protein pools in the sediment collected in October 2005 at $1000 \mathrm{~m}$ depth were significantly higher than that in the other sampling periods at similar depth. Such a contribution increased significantly with increasing water depth in the sediments of open slope collected in August 2006. Similar patterns were observed for the enzymatically hydrolysable carbohydrates whose contribution significantly increased with water depth in August 2006 both in the open slope and canyon sediments.
The fraction of the two enzymatically hydrolysable pools generally did not change significantly between canyon and open slope sediments.

The concentrations of bioavailable $\mathrm{C}$ in surface sediments (range: $94-345 \mu \mathrm{g} \mathrm{g}^{-1}$ ) were characterized by significant spatial and temporal changes (Fig. 4a, Table S2). The post hoc test revealed that bioavailable $\mathrm{C}$ content in the sediment collected in May 2004 (at $1000 \mathrm{~m}$ depth in the open slope and at $1900 \mathrm{~m}$ in the canyon) was significantly higher than in the other sampling periods. Slope sediments collected in October 2005 and August 2006 were also characterized by values of bioavailable C concentrations significantly higher at $1900 \mathrm{~m}$ depth than at $1000 \mathrm{~m}$ depth. The contribution of bioavailable $\mathrm{C}$ to the total biopolymeric $\mathrm{C}$ pools (range: $6 \pm 1$ $29 \pm 7 \%$ ) displayed significant temporal and spatial changes with values significantly lower at $1000 \mathrm{~m}$ than at $1900 \mathrm{~m}$ depth (Fig. 4b, Table S2; data on biopolymeric C are reported in the supplementary material). In May 2004 the enzymatically hydrolysable proteins in the sediments represented the dominant component of the bioavailable $\mathrm{C}$ pools (on average $60 \%$ ), which, conversely, in August 2006 was mainly composed by $\mathrm{C}$ associated with enzymatically hydrolysable carbohydrates (on average $70 \%$; Fig. 4c). The contribution of enzymatically proteins to bioavailable $\mathrm{C}$ pools was similar or even significantly higher in the sediments collected at $1900 \mathrm{~m}$ depth than in those collected at $1000 \mathrm{~m}$ depth (Table S2).

\subsection{Bioavailability of organic matter in sediments of the Portuguese margin}

Total phytopigment concentrations in surface sediments of the Portuguese margin ranged from $3.7 \pm 0.1$ to $46.9 \pm 2.9 \mu \mathrm{g} \mathrm{g}^{-1}$ and were characterized by values significantly higher in the Nazarè canyon than in the adjacent open slope at all depths (Fig. 5a, Table S4). The post hoc comparison revealed a significant decrease of total phytopigment concentrations with increasing water depth in the canyon and a significant increase in the adjacent open slope (Table S4). In slope sediments HPRT concentrations did not change significantly with increasing water depth, whereas in the canyon significant changes with water depth were observed (Fig. 5b, Table S4). In particular, in the canyon the lowest HPRT concentrations were determined in the sediment collected at $960 \mathrm{~m}$ depth (post hoc $p<0.01$ ). Sediments collected within the canyon were also characterized by HPRT concentrations significantly higher than those determined in the adjacent open slope at similar depths. HCHO concentrations were significantly higher in the sediments of the upper part of the canyon and vice versa in the open slope (Fig. 5c, Table S4). The enzymatically hydrolysable carbohydrate pools did not differ significantly between canyon and open slope sediments, with the exception of samples collected at $960 \mathrm{~m}$ depth. 


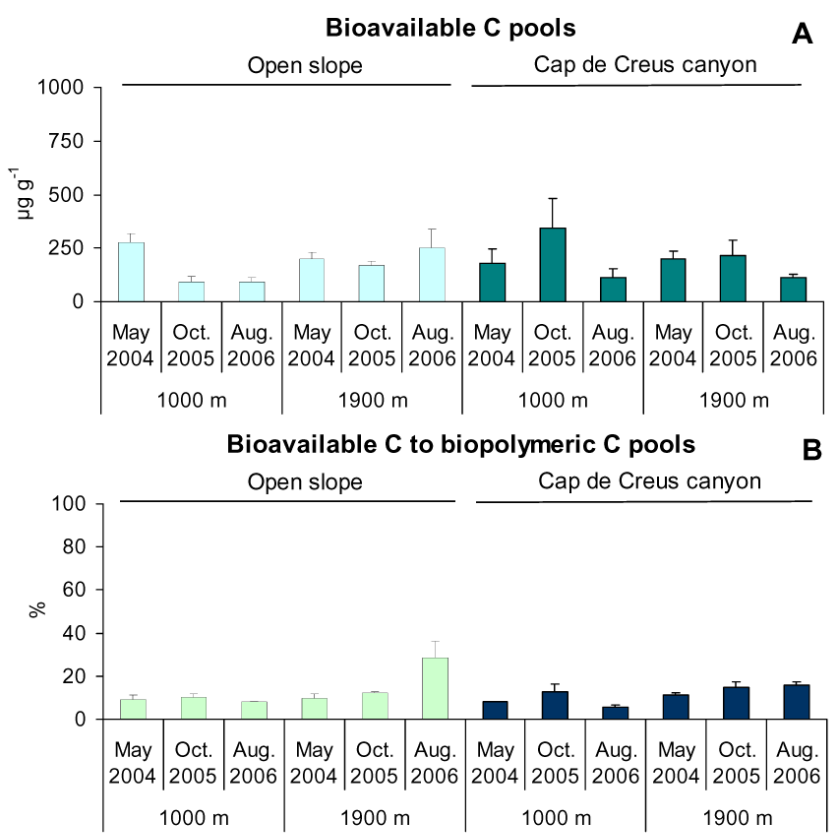

Hydrolysable proteins to bioavailable $C$ pools

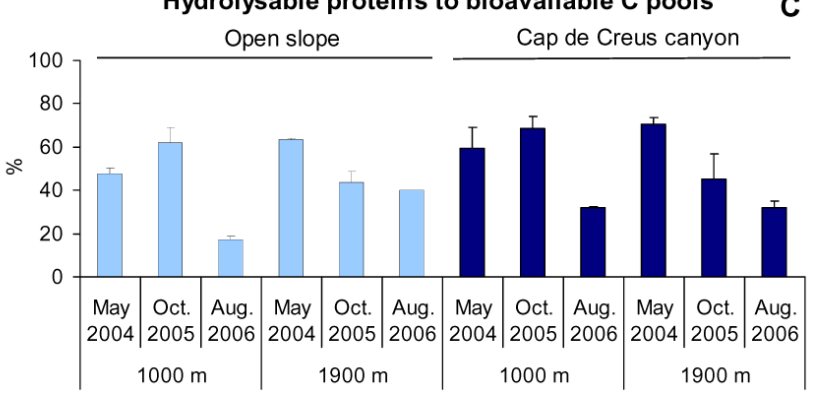

Fig. 4. Spatial distribution of (A) bioavailable $C$ concentrations, (B) contribution of bioavailable $\mathrm{C}$ to biopolymeric $\mathrm{C}$ pools and $(\mathbf{C})$ contribution of hydrolysable proteins (converted into $\mathrm{C}$ equivalents) to bioavailable $\mathrm{C}$ pools in surface sediments of the Cap de Creus canyon and adjacent open slope of the Catalan margin collected in the different sampling periods. Standard deviations are reported.

In the sediments of the open slope of the Portuguese margin, the contribution of enzymatically hydrolysable proteins to the total protein pools decreased significantly with increasing water depth (Fig. 6a; data on TPRT concentrations are reported in Table S5 of the supplementary material). Conversely, in the canyon such a contribution significantly increased with increasing water depth. At shallower depths the contribution of enzymatically hydrolysable proteins to the total protein pools were significantly higher in open slope than in the canyon sediments and vice versa at greater depths. The contribution of enzymatically hydrolysable carbohydrates to the total carbohydrate pools decreased significantly with increasing water depths both in the canyon and in the adjacent open slope (Fig. 6b; data on TCHO concentrations are reported in Table S5 of the supplementary material). At all

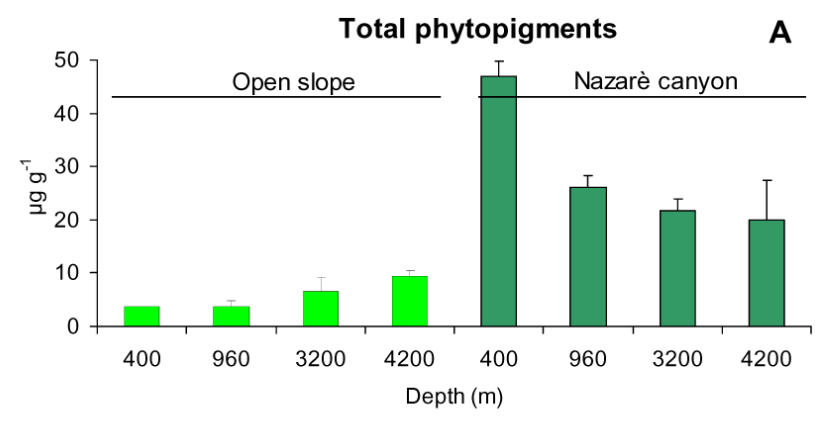

Hydrolysable proteins
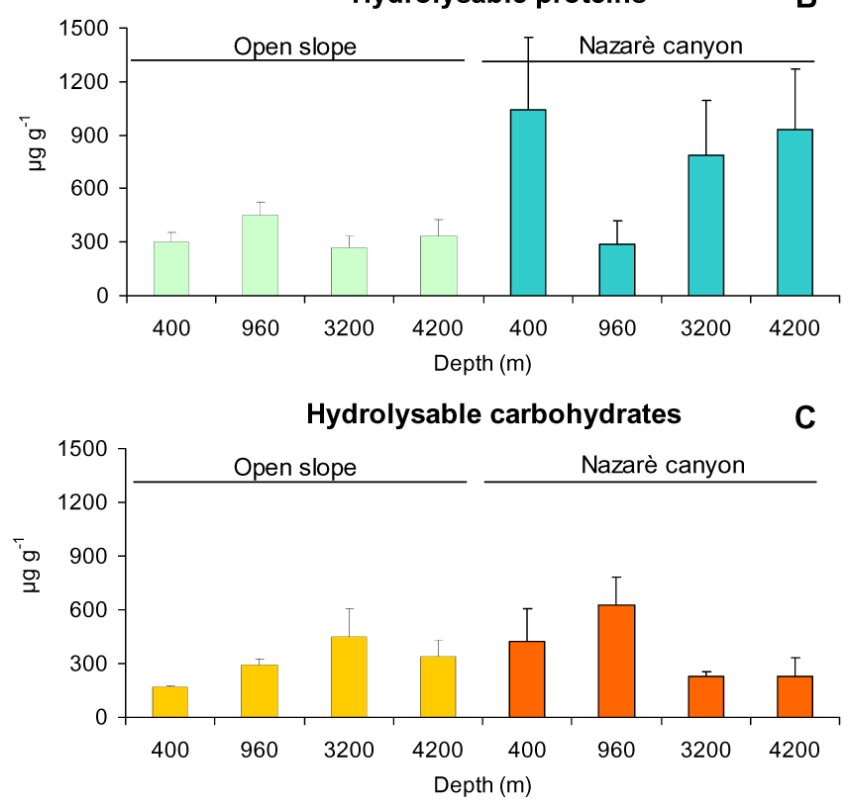

Fig. 5. Spatial distribution of (A) total phytopigment concentrations, (B) enzymatically hydrolysable protein and (C) carbohydrate pools in surface sediments of the Nazarè canyon and adjacent open slope of the Portuguese margin. Standard deviations are reported.

depths such a contribution was significantly higher in open slope than in canyon sediments.

Bioavailable $\mathrm{C}$ concentrations in surface deep-sea sediments ranged from $218 \pm 50$ to $680 \pm 272 \mu \mathrm{g} \mathrm{g}^{-1}$ (at shallowest depths both in the open slope and the Nazarè canyon; Fig. 7a). Bioavailable $\mathrm{C}$ concentrations did not vary significantly with increasing water depth within the canyon, whereas significant lower values in the adjacent open slope were observed at the shallowest depth (Table S4). Canyon sediments were characterized by bioavailable $\mathrm{C}$ concentrations significantly higher than those determined in the open slope sediments at similar depths.

The contribution of bioavailable $\mathrm{C}$ to the biopolymeric $\mathrm{C}$ pools (data on BPC concentrations are reported in Table S5) ranged from $14 \pm 1$ to $58 \pm 6 \%$ and displayed a significant increase with increasing water depth in the canyon (Fig. 7b, Table S4). Conversely, in the open slope such a contribution significantly decreased with increasing water depth. The 

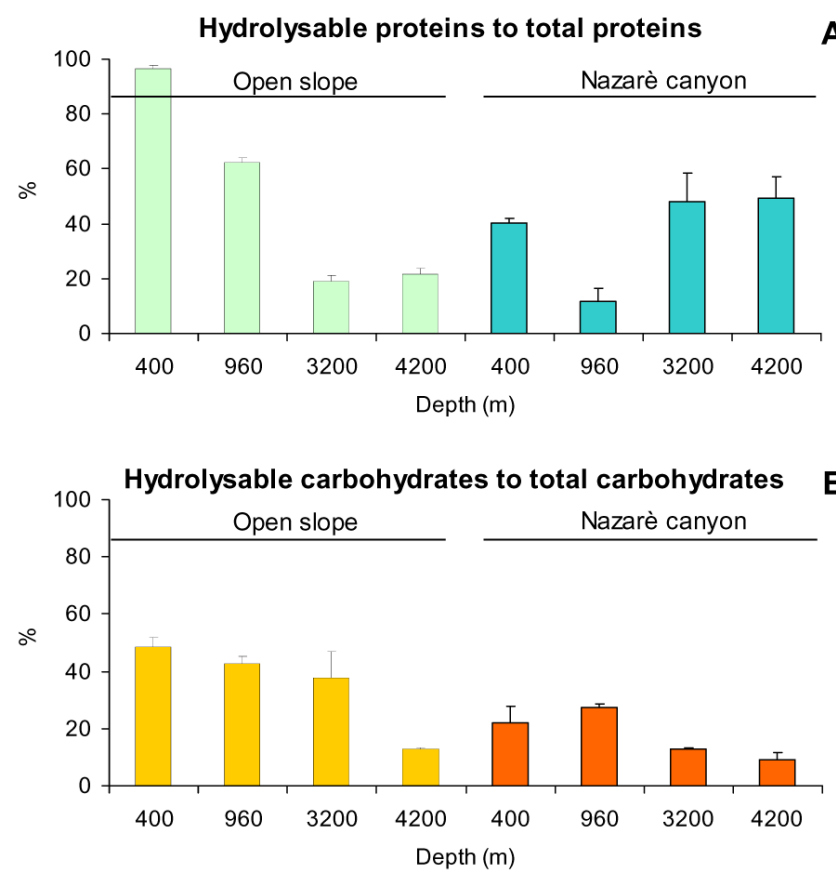

Fig. 6. Spatial patterns of the contribution of (A) enzymatically hydrolysable proteins and (B) carbohydrates to their respective total pools in surface sediments of the Nazarè canyon and adjacent open slope of the Portuguese margin. Standard deviations are reported.

bioavailable $\mathrm{C}$ fraction was significantly higher in the open slope sediments located at shallower depths than that of the canyon sediments at similar depths and vice versa for the deepest station.

The enzymatically hydrolysable proteins accounted, on average, for 58 and $69 \%$ of the bioavailable $\mathrm{C}$ pools in open slope and Nazarè canyon sediments, respectively (Fig. 7c). In the sediments of the Nazarè canyon, such a contribution significantly increased with increasing water depths (up to $83 \%$ at the deepest station), which, conversely in the open slope significantly decreased (down to $42 \%$ at $3200 \mathrm{~m}$ depth; Table S4).

\section{Discussion}

Primary production in ocean surface waters fuels the deepsea ecosystems through particle export from the euphotic zone (Dunne et al., 2007). Mechanisms of particle transfer to deep continental margins depend not only upon particle sedimentation from the upper ocean, but also upon a wide array of processes, including down slope and down canyon transport, rebound of re-suspended particles and episodic events such as sediment laden flows and DSWC (Canals et al., 2006; Heussner et al., 2006; de Stigter et al., 2007). Altogether, these factors drive distribution and accumulation of organic matter in surface sediments of continental margins.
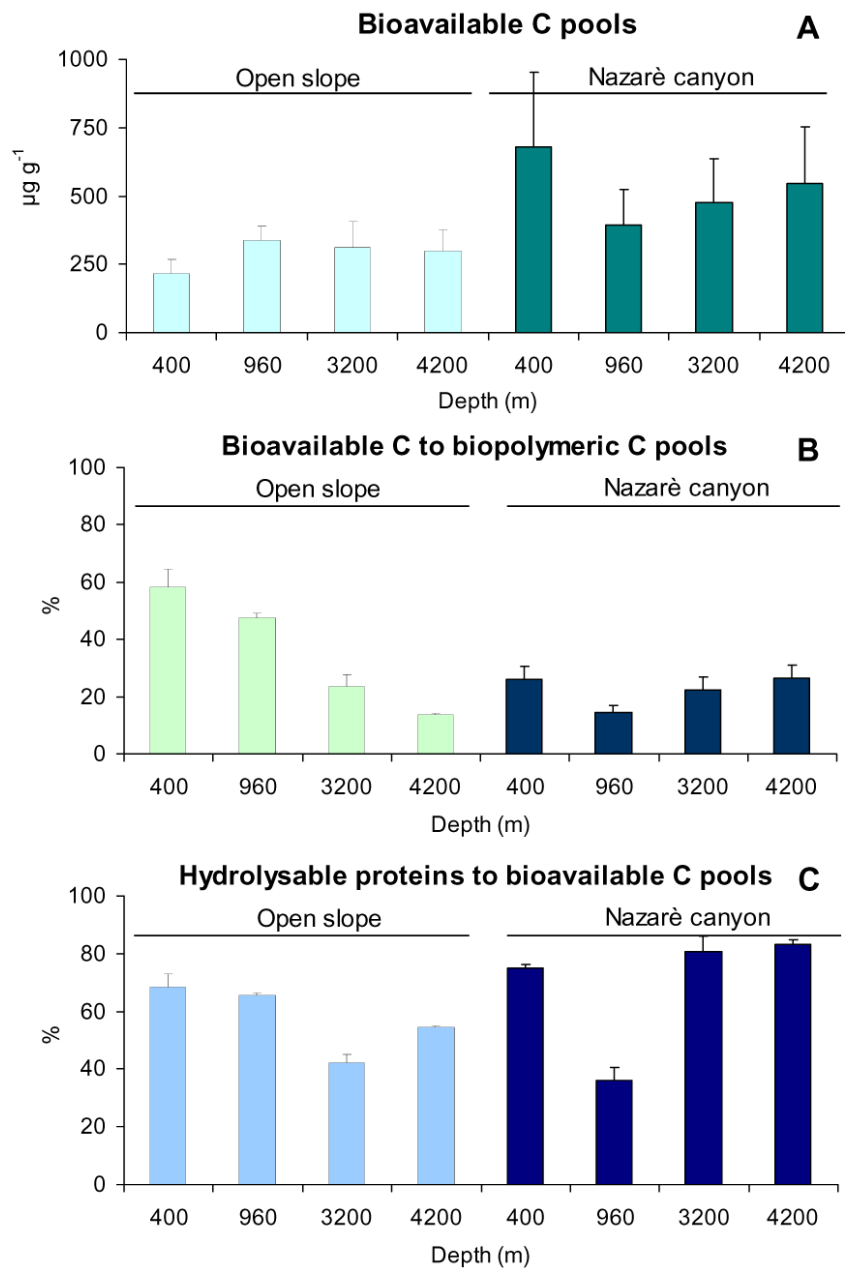

Fig. 7. Spatial distribution of (A) bioavailable $\mathrm{C}$ concentrations, (B) contribution of bioavailable $\mathrm{C}$ to biopolymeric $\mathrm{C}$ pools and $(\mathbf{C})$ contribution of hydrolysable proteins (converted into $\mathrm{C}$ equivalents) to bioavailable $\mathrm{C}$ pools in surface sediments of the Nazarè canyon and adjacent open slope of the Portuguese margin. Standard deviations are reported.

In this study differences in primary productivity between surface waters of the two continental margins (ca. 2-fold higher in the Portuguese margin) were reflected by total phytopigment concentrations, which were significantly higher in the sediments of the Nazarè canyon than in Cap the Creus canyon despite samples were collected almost synoptically at similar depth. Conversely, slope sediments of the Portuguese margin were characterized by significantly lower phytopigment concentrations than those of the Catalan margin. Such a spatial variability of photosynthetically-produced organic matter deposited on surface sediments suggests that the pelagic-benthic coupling mechanisms may be also controlled by the geomorphological characteristics and hydrological processes characterizing the two environments (i.e., canyon vs. open slope). 
Previous studies have inferred the amount of labile organic matter in surface deep-sea sediments through the analysis of chlorophyll $a$ concentrations (van Oevelen et al., 2011, 2012). However, chlorophyll $a$ is rapidly converted into degradation products during particle sinking to the ocean floor (Fabiano et al., 2001) and rapidly decays in the sediments (Sun et al., 1991). Moreover, the pool size of labile organic matter in the sediment estimated from chlorophyll $a$ concentrations can vary depending on the conversion factor applied, i.e. $30-100 \mu \mathrm{gC} \mu \mathrm{g}$ chlorophyll $a^{-1}$ (Pusceddu et al., 2009).

In this study we estimated the bioavailability of organic matter in sediments of the Portuguese and Catalan margins through an enzymatic approach. Such an approach, despite its intrinsic limitations, has been extensively used across a wide range of benthic ecosystems to provide quantitative information on food availability for heterotrophic consumers (Mayer et al., 1995, 2008; Dauwe et al., 1999a; Dell'Anno et al., 2000; Danovaro et al., 2001a; Pusceddu et al., 2003; Grémare et al., 2005; Bourgeois et al., 2011).

We found that the enzymatically hydrolyzed protein and carbohydrate pools in the sediments of the Nazarè canyon were 3-4 fold higher than those of Cap de Creus canyon at similar depth. Also, slope sediments of the Portuguese margin were characterized by significantly higher enzymatically hydrolyzed organic matter concentrations when compared to slope sediments of the Catalan margin. The comparison with available literature information indicates that the sediments investigated in this study are characterized by enzymatically hydrolyzed protein and carbohydrate concentrations similar to those determined in shallow benthic systems (Pusceddu et al., 2003; Mayer et al., 2008 and citations therein for a comparison with results based on different approaches/protocols), but up to 2-3 fold higher than those determined in abyssal sediments of the NE Atlantic Ocean (Dell'Anno et al., 2000; Danovaro et al., 2001a). The lower amount of enzymatically digestible organic matter pools in abyssal sediments of the NE Atlantic Ocean is consistent with the lower organic carbon inputs reaching the seafloor (ca. $1 \mathrm{gC} \mathrm{m}^{-2} \mathrm{yr}^{-1}$ at $4700 \mathrm{~m}$ depth; Lampitt et al., 2001).

Phytodetritus sinking from the water column represents a major source of bioavailable organic matter to the deepsea floor (Fabiano et al., 2001; Dell'Anno and Danovaro, 2005). In this study we found a significant relationship between enzymatically hydrolyzed protein concentrations and phytopigment contents in the sediments of the Portuguese margin $(n=8, r=0.723, p<0.05)$, though this was not the case for the Catalan margin. High concentrations of nonalgal bioavailable organic $\mathrm{N}$ compounds (in terms of enzymatically hydrolysable aminoacids) have been documented in benthic systems influenced by major river outflows (Mayer et al., 2008; Bourgeois et al., 2011), including sediments previously collected in the Gulf of Lion (Grémare et al., 2005; Bourgeois et al., 2011). Previous findings, based on temporal investigations carried out by mooring trap arrays deployed at ca. $1000 \mathrm{~m}$ and $1900 \mathrm{~m}$ depth (in the same stations investigated in the present study), provided evidence that, during the DSWC events occurring during winter/early spring 2005 and 2006, Cap de Creus canyon and the adjacent southern open slope received high amounts of organic material (up to ca. $75 \%$ of the total annual organic matter fluxes; SanchezVidal et al., 2008, 2009; Pasqual et al., 2010). Such huge inputs of organic material to the deep margin and basin are represented not only by organic particles of marine origin (due to the phytoplankton bloom occurring concomitantly on the shelf), but also by large amounts of organic particles of terrestrial origin (i.e. mainly from the Rhone River) resuspended on the shelf and transported down canyon and down slope (Canals et al., 2006; Sanchez-Vidal et al., 2008, 2009; Pasqual et al., 2010). Moreover, stable isotope and biochemical analyses revelead that this organic material settling on the seafloor was relatively labile (Sanchez-Vidal et al., 2008, 2009). Therefore, our results suggest that such episodic events involving massive organic particle transport from the shelf to the deep margin and basin can represent an important mechanism which fuels the benthic systems of the Catatan margin with bioavailable $\mathrm{N}$-rich compounds.

Open slope sediments from the two continental margins investigated here were characterized by a significant increase of bioavailable organic $\mathrm{C}$ concentrations with increasing water depth. Such depth-related patterns of bioavailable organic matter are consistent with previous studies carried out in the same areas, based on the use of other proxies of sediment trophic state, i.e. total and/or enzymatically hydrolysable aminoacids (Grèmare et al., 2005; García and Thomsen, 2008). No significant differences in bioavailable $C$ concentrations with increasing water depth were observed either in the sediments of the Nazarè canyon or in those of Cap de Creus canyon. These results suggest that the lateral transport of organic particles from shallow to bathyal depths, even amplified by episodic events such as gravity flows in the Nazarè canyon and DSWC in the Catalan margin (Heussner et al., 2006; Canals et al., 2006; Palanques et al., 2006, 2012; de Stigter et al., 2007; Arzola et al., 2008), may have important implications on the quantity and distribution of bioavailable $\mathrm{C}$ pools in the sediments.

In this study differences in the trophic state (as bioavailable $\mathrm{C}$ pools) between canyons and the adjacent open slopes were more evident in the Portuguese than in the Catalan margin. Bioavailable $\mathrm{C}$ concentrations in surface sediments of the Nazarè canyon were, indeed, significantly higher than those in the adjacent open slope (on average, $524 \pm 26$ vs. $292 \pm 61 \mu \mathrm{g} \mathrm{g}^{-1}$ ), whereas no significant differences between environments were generally observed in the Catalan margin. The sediments of the Nazarè canyon were also characterized by a higher nutritional value of bioavailable organic matter than those of the open slope, as revealed by the higher contribution of enzymatically digestible proteins to the BAOC pools. Such trophic characteristics allow us to hypothesize, according to the optimal foraging 
theory (McArthur and Pianka, 1966), that benthic detritus feeders inhabiting the Nazarè canyon may have relevant energetic/metabolic advantages compared to those inhabiting the open slopes. These findings provide additional support to explain why higher meiofaunal and macrofaunal standing stocks are reported in the Nazarè canyon compared with the adjacent open slopes at similar depths (Ingels et al., 2009; Cunha et al., 2011). Moreover, the enhanced nutritional value of bioavailable organic detritus with increasing water depth can contribute, along with other factors previously suggested (e.g., level of physical disturbance and spatial heterogeneity), to justify the distribution patterns of macrofaunal abundances, i.e. up to ca. 10-fold higher at $3200-3400 \mathrm{~m}$ than at 940-1000 m depth (Cunha et al., 2011; Paterson et al., 2011).

Despite the limited spatial differences observed comparing canyon against open slope settings in the Catalan margin, significant temporal changes were observed. Bioavailable organic $\mathrm{C}$ pools as well as their nutritional value (in terms of the relative importance of enzymatically digested proteins to the bioavailable $\mathrm{C}$ pools) were significantly higher in May 2004 than in the other sampling periods in both environments, Cap de Creus canyon and the adjacent open slope. This difference, also observed in other canyons nearby the Gulf of Lion (Lopez-Fernandez et al., 2013), may be attributed to the phytoplankton spring bloom reported for the NW Mediterranean (Estrada et al., 1996; Lefevre et al., 1997). We can therefore infer that, according to the optimal foraging theory (McArthur and Pianka, 1966), in spring deep-sea detritus feeders would need to ingest less material than in summer/early autumn to get the optimal quantity and quality of labile food. Temporal differences in the nutritional value of bioavailable organic matter pools were also evident when comparing sediments collected at the same depths in October 2005 and August 2006. In particular, bioavailable organic C pools in the sediments collected in October 2005 were mainly represented by labile proteins (on average $55 \%$ ) whose contribution significantly decreased in the sediments collected in August 2006 (on average 30\%).

There is an increasing consensus that deep-sea ecosystems are more dynamic than previously hypothesized (Smith and Kaufmann, 1999; Danovaro et al., 2001b; Ruhl and Smith, 2004; Ruhl et al., 2008; Billett et al., 2010), and that important changes in quantity and composition of bioavailable organic matter deposited on the ocean floor occur both at seasonal and inter-annual time scales (Danovaro et al., 2001a; Fabiano et al., 2001; Dell'Anno et al., 2005; Smith et al., 2010). Our results from the Catalan margin reinforce this view and suggest that DSWC events may amplify the temporal variability of the trophic state of benthic deep-sea ecosystems related to changes in biological production of the photic zone. Since DSWC events occur along continental margins around the world oceans (Ivanov et al., 2004; Canals et al., 2009), long-term and wide spatial-scale investigations of bio-geosphere interactions are needed to better understand the impact of these events on the bioavailability of organic matter and related implications on benthic trophodynamics and ecosystem functioning.

\section{Supplementary material related to this article is available online at: http://www.biogeosciences.net/10/ 2945/2013/bg-10-2945-2013-supplement.pdf.}

Acknowledgements. This study has been conducted within the framework of the European funded Projects HERMES (Hotspot Ecosystem Research on the Margins of European Seas; GOCE-CT2005-511234-1) and HERMIONE (Hotspot Ecosystem Research and Man's Impact On European Seas; contract no. 226354) and the Spanish projects DOS MARES (CTM2010-21810-C03-01) and REDECO (ref. CTM2008-04973-E/MAR). University of Barcelona researchers benefited from grant 2009SGR1305 by Generalitat de Catalunya to excellence research groups. The authors are indebted to the crews of the ships Pelagia (The Netherlands), Urania (Italy) and Thetis II (France) for their valuable help during field activities.

Edited by: A. Boetius

\section{References}

Alvarez-Salgado, X. A., Figueiras, F. G., Perez, F. F., Groom, S., Nogueira, E., Borges, A. V., Chou, L., Moncoiffe, G., Rios, A. F., Miller, A. E. J., Frankignoulle, M., Savidge, G., and Wollast, R.: The Portugal coastal counter current off NW Spain: new insights on its biogeochemical variability, Prog. Oceanogr., 56, 281-321, 2003.

Anderson, M. J., Gorley, R. N., and Clarke, K. R.: PERMANOVA+ for PRIMER: Guide to software and statistical methods, PRIMER-E: Plymouth, UK, 2008.

Arzola, R. G., Wynn, R. B., Lastras, G. B., Masson, D. G., and Weaver, P. P. E.: Sedimentary features and processes in the Nazarè and Setubal submarine canyons, west Iberian margin, Mar. Geol., 250, 64-88, 2008.

Bauer, J. E. and Druffel, E. R. M.: Ocean margins as a significant source of organic matter to the deep open ocean, Nature, 392 482-485, 1998..

Bianchelli, S., Gambi, C., Zeppilli, D., and Danovaro, R.: Metazoan meiofauna in deep-sea canyons and adjacent open slopes: A large-scale comparison with focus on the rare taxa, Deep-Sea Res. I, 57, 420-433, 2010.

Billett, D. S. M., Bett, B. J., Reid, W. D. K., Boorman, B., and Priede, M.: Long-term change in the abyssal NE Atlantic: The 'Amperima Event' revisited, Deep-Sea Res. II, 57, 1406-1417, 2010.

Bourgeois, S., Pruski, A. M., Sun, M.-Y., Buscail, R., Lantoine, F., Kerhervé, P., Vétion, G., Rivière, B., and Charles, F.: Distribution and lability of land-derived organic matter in the surface sediments of the Rhône prodelta and the adjacent shelf (Mediterranean Sea, France): a multi proxy study, Biogeosciences, 8, 3107-3125, doi:10.5194/bg-8-3107-2011, 2011. 
Buscail, R. and Germain, C.: Present-day organic matter sedimentation on the NW Mediterranean margin: importance of off-shelf export, Limnol. Oceanogr., 42, 217-229, 1997.

Buscail, R., Pocklington, R., and Germain, C.: Seasonal variability of the organic matter in a sedimentary coastal environment: sources, degradation and accumulation (continental shelf of the Gulf of Lions-northwestern Mediterranean Sea), Cont. Shelf. Res., 15, 843-869, 1995.

Canals, M., Puig, P., Durrieu de Madron, X., Heussner, S., Palanques, A., and Fabres J.: Flushing submarine canyons, Nature, 444, 354-357, 2006.

Canals, M., Danovaro, R.,. Heussner, S., Lykousis, V., Puig, P., Trincardi, F., Calafat, A. M., Durrieu de Madron, X., Palanques, A., and Sànchez-Vidal, A.: Cascades in Mediterranean submarine grand canyons, Oceanography, 22, 26-43, 2009.

Cunha, M. R., Paterson, G. L. J., Amaro, T., Blackbird, S., de Stigter, H. C., Ferreira, C., Glover, A., Hilário, A., Kiriakoulakis, K., Neal, L., Ravara, A., Rodrigues, C. F., Tiago, Á., and Billett, D. S. M.: Biodiversity of macrofaunal assemblages from three Portuguese submarine canyons (NE Atlantic), Deep-Sea Res. II, 58, 2433-2447, 2011.

Danovaro, R., Dell'Anno, A., and Fabiano, M.: Bioavailability of organic matter in the sediments of the Porcupine Abyssal Plain, northeastern Atlantic, Mar. Ecol. Prog. Ser., 220, 25-32, 2001a.

Danovaro, R., Dell'Anno, A., Fabiano, M., Pusceddu, A., and Tselepides, A.:

Deep-sea ecosystem response to climate changes: the eastern Mediterranean case study, Trends Ecol. Evol., 16, 505-510, $2001 b$.

Danovaro, R., Della Croce, N., Dell'Anno, A., and Pusceddu, A.: A depocenter of organic matter at $7800 \mathrm{~m}$ depth in the SE Pacific Ocean, Deep-Sea Res. I, 50, 1411-1420, 2003.

Danovaro, R., Dell'Anno, A., Corinaldesi, C., Magagnini, M., Noble, R., Tamburini, C., and Weinbauer, M.: Major viral impact on the functioning of benthic deep-sea ecosystems, Nature, 454, 1084-1087, 2008a.

Danovaro, R., Gambi, C., Dell'Anno, A., Corinaldesi, C., Fraschetti, S., Vanreusel, A., Vincx, M., and Gooday, A. J.: Exponential decline of deep-sea ecosystem functioning linked to benthic biodiversity loss, Cur. Biol., 18, 1-8, 2008b.

Danovaro, R.: Methods for the study of deep-sea sediments, their functioning and biodiversity, CRC press, Taylor \& Francis Group, USA, 2010.

Danovaro, R., Canals, M., Gambi, C., Heussner, S., Lampadariou, N., and Vanreusel, A.: Exploring benthic biodiversity patterns and hotspots on European margin slopes, Oceanography, 22, 1625, 2010.

Dauwe, B., Middelburg, J. J., Van-Rijswijk, P., Sinke, J., Herman, P. M. J., and Heip, C. H. R.: Enzymatically hydrolyzable amino acids in North Sea sediments and their possible implication for sediment nutritional values, J. Mar. Res., 57, 109-134, 1999a.

Dauwe, B., Middelburg, J. J., Herman, P. M. J., and Heip, C. H. R.: Linking diagenetic alteration of amino acids and bulk organic matter reactivity, Limnol. Oceanogr., 44, 1809-1814, 1999b.

De Leo, F. C., Smith, C. R., Rowden, A. A., Bowden, D. A., and Clark, M. R.: Submarine canyons: hot spots of benthic biomass and productivity in the deep sea, P. Roy. Soc B-Biol Sci., 277, 2783-2792, 2010. de Stigter, H. C., Boer, W., de Jesus Mendes, P.A., Jesus, C. C., Thomsen, L., van den Bergh, G. D., and van Weering, T. C. E.: Recent sediment transport and deposition in the Nazarè Canyon, Portuguese continental margin, Mar. Geol., 246, 144-164, 2007.

Dell'Anno, A., and Danovaro, R.: Extracellular DNA plays a key role in deep-sea ecosystem functioning, Science, 309, p. 2179, 2005.

Dell'Anno, A., Fabiano, M., Mei, M. L., and Danovaro, R.: Enzymatically hydrolised protein and carbohydrate pools in deep-sea sediments: estimates of the potential bioavailable fraction and methodological considerations, Mar. Ecol. Prog. Ser., 196, 1523, 2000.

Dell'Anno, A., Mei, M. L., Pusceddu, A., and Danovaro, R.: Assessing the trophic state and eutrophication of coastal marine systems: a new approach based on the biochemical composition of sediment organic matter, Mar. Poll. Bull., 44, 611-622, 2002.

Dell'Anno, A., Corinaldesi, C., Stavrakakis, S., Lykousis, V., and Danovaro, R.: Pelagic-benthic coupling and diagenesis of nucleic acids in a deep-sea continental margin and an open-slope system of the Eastern Mediterranean, Appl. Environ. Microbiol., 71, 6070-6076, 2005.

Dunne, J. P., Sarmiento, J. L., and Gnanadesikan, A.: A synthesis of global particle export from the surface ocean and cycling through the ocean interior and on the seafloor, Global Biogeochem. Cycles, 21, GB4006, doi:10.1029/2006GB002907, 2007.

Estrada, M.: Primary production in the northwestern Mediterranean. Sci. Mar., 60, 55-64, 1996.

Epping, E., van der Zee, C., Soetaert, K., and Helder, W.: On the oxidation and burial of organic carbon in sediments of the Iberian margin and Nazarè Canyon (NE Atlantic), Prog. Oceanogr., 52, 399-431, 2002.

Fabiano, M., Danovaro, R., and Fraschetti, S.: A three-year time series of elemental and biochemical composition of organic matter in subtidal sandy sediments of the Ligurian Sea (north western Mediterranean), Cont. Shelf Res., 15, 1453-1469, 1995.

Fabiano, M., Pusceddu, A., Dell'Anno, A., Armeni, M., Vanucci, S., Lampitt, R., Wolff, G., and Danovaro, R.: Fluxes of phytopigments and labile organic matter to the deep ocean in the NE Atlantic Ocean, Prog. Oceanogr., 50, 89-104, 2001.

García, R., and Thomsen, L.: Bioavailable organic matter in surface sediments of the Nazarè canyon and adjacent slope (Western Iberian Margin), J. Mar. Syst., 74, 44-59, 2008.

George, J. D.: Organic matter available to the polychaete Cirriformia tentaculata (Montagu) living in an intertidal mud flat, Limnol. Oceanogr., 9, 453-455, 1964.

Gooday, A. J.: Biological responses to seasonally varying fluxes of organic matter to the ocean floor: a review, J. Oceanogr., 58, 305332, 2002.

Grémare, A., Gutiérrez, D., Anschutz, P., Amouroux, J. M., Deflandre, B., and Vétion, G.: Spatio-temporal changes in totally and enzymatically hydrolyzable amino acids of superficial sediments from three contrasted areas, Prog. Oceanogr., 65, 89-111, 2005.

Heussner, S., Durrieu de Madron X., Calafat A., Canals, M., Carbonne, J., Delsaut, N., and Saragoni, G.: Spatial and temporal variability of downward particle fluxes on a continental slope: Lessons from an 8-yr experiment in the Gulf of Lions (NW Mediterranean), Mar. Geol. 234: 63-92, 2006.

Ingels, J., Kiriakoulakis, K., Wolff, G. A., and Vanreusel, A.: Nematode diversity and its relation to the quantity and quality of 
sedimentary organic matter in the deep Nazarè Canyon, Western Iberian Margin. Deep-Sea Res., 56, 1521-1539, 2009.

Ivanov, V. V., Shapiro, G. I., Huthnance, J. M., Aleynik, D. L., and Golovin, P. N.: Cascades of dense water around the world ocean, Progr. Oceanogr., 60, 47-98, 2004.

Kiriakoulakis, K., Blackbird, S., Ingels, J., Vanreusel, A., and Wolff, G. A.: Organic geochemistry of submarine canyons: The Portuguese Margin, Deep-Sea Res. II, 58, 2477-2488, 2011.

Lampitt, R. S., Bett, B. J., Kiriakoulakis, K., Popova, E. E., Ragueneau, O., Vangriesheim, A., and Wolff, G. A.: Material supply to the abyssal seafloor in the Northeast Atlantic, Prog. Oceanogr., 50, 27-63, 2001.

Lefevre, D., Minas, H. J., Minas, M., Robinson, C., Williams, P. J. L. E. B., and Woodward, E. M. S.: Review of gross community production, primary production, net community production and dark community respiration in the Gulf of Lions, Deep-Sea Res., 44, 801-832, 1997.

Liu, K-K., Atkinson, L., Quiñones, R., and Talaue-McManus, L.: Carbon and nutrient fluxes in continental margins: a global synthesis, Springer-Verlag, Berlin Heidelberg, 2010.

López-Fernández, P., Bianchelli, S., Pusceddu, A., Calafat, A., Danovaro, R., and Canals, M.: Bioavailable compounds in sinking particulate organic matter, Blanes Canyon, NW Mediterranean Sea: effects of a large storm and sea surface biological processes, Progr. Oceanogr., in press, 2013.

Lorenzen, C. and Jeffrey, J.: Determination of chlorophyll in seawater. Technical Paper in Marine Science (UNESCO), 35, 1-20, 1980.

Martìn, J., Palanques, A., Vitorino, J., Oliveira, A., and de Stigter, H. C.: Near-bottom particulate matter dynamics in the Nazarè submarine canyon under calm and stormy conditions, Deep-Sea Res. II, 58, 2388-2400, 2011.

Masson, D. G., Huvenne, V. A. I., de Stigter, H. C., Wolff, G. A., Kiriakoulakis, K., Arzola, R. G., and Blackbird, S.: Efficient burial of carbon in a submarine canyon, Geology, 38, 831-834, 2010.

Mayer, L. M.: Sedimentary organic matter preservation: an assessment and speculative synthesis - a comment, Mar. Chem., 49, 123-126, 1995.

Mayer, L. M., Schick, L. L., Sawyer, T., Plante, C. J., Jumars, P. A., and Self, R. L.: Bioavailable amino acids in sediments: a biomimetic, kinetics-based approach, Limnol. Oceanogr., 40, 511-520, 1995.

Mayer, L. M., Schick, L. L., and Allison, M. A.: Input of nutritionally rich organic matter from the Mississippi river to the Louisiana coastal Zone, Estuar. Coast., 31, 1052-1062, 2008.

MacArthur, R. H. and Pianka, E. R.: On the optimal use of a patchy environment, Am. Nat., 100, 603-609, 1966.

McClain, C. R. and Barry, J. P.: Habitat heterogeneity, disturbance, and productivity work in concert to regulate biodiversity in deep submarine canyons, Ecology, 91, 964-976, 2010.

Middelburg, J. J. and Meysman, F. J. R.: Burial at sea, Science, 317, 1294-1295, 2007.

Middelburg, J. J., Nieuwenhuize, J., and van Breugel, P.: Black carbon in marine sediments, Mar. Chem., 65, 245-252, 1999.

Millot, C.: The Gulf of Lions' hydrodynamics, Cont. Shelf Res., 10, 885-894, 1990.

Palanques, A., Durrieu de Madron, X., Puig, P., Fabres, J., Guilleñ, J., Calafat, A., Canals, M., Heussner, S., and Bonnin, J.: Sus- pended sediment fluxes and transport processes in the Gulf of Lions submarine canyons. The role of storms and dense water cascading, Mar. Geol., 236, 43-61, 2006.

Palanques, A., Puig, P., Durrieu de Madron, X., Sanchez-Vidal, A., Pasqual, C., Martín, J., Calafat, A., Heussner, S., and Canals, M.: Sediment transport to the deep canyons and open-slope of the western Gulf of Lions during the 2006 intense cascading and open-sea convection period, Progr. Oceanogr., 106, 1-15, 2012.

Pasqual, C., Sanchez-Vidal, A., Zúñiga, D., Calafat, A., Canals, M., Durrieu de Madron, X., Puig, P., Heussner, S., Palanques, A., and Delsaut, N.: Flux and composition of settling particles across the continental margin of the Gulf of Lion: the role of dense shelf water cascading, Biogeosciences, 7, 217-231, doi:10.5194/bg-7217-2010, 2010.

Paterson, G. L. J., Glover, A. G., Cunha, M. R., Neal, L., de Stigter, H. C., Kiriakoulakis, K., Billett, D. S. M., Wolff, G. A., Tiago, A., Ravara, A., Lamont, P., and Tyler P.: Disturbance, productivity and diversity in deep-sea canyons: A worm's eye view, Deep-Sea Res. II, 58, 2448-2460, 2011.

Pusceddu, A., Dell'Anno, A., Danovaro, R., Manini, E., Sarà, G., and Fabiano, M.: Enzymatically hydrolyzable protein and carbohydrate sedimentary pools as indicators of the trophic state of 'detritus sink' systems: a case study in a Mediterranean coastal lagoon, Estuaries, 26, 641-650, 2003.

Pusceddu, A., Dell'Anno, A., Fabiano, M., and Danovaro, R.: Quantity, biochemical composition and bioavailability of sediment organic matter as complementary signatures of benthic trophic status, Mar. Ecol. Prog. Ser. 375, 41-52, 2009.

Pusceddu, A., Bianchelli, S., Sanchez Vidal, A., Canals, M., Durrieu De Madron, X., Heussner, S., Lykousis, V., de Stigter, H., Trincardi, F., and Danovaro, R.: Organic matter in sediments of canyons and open slopes in the Eastern Atlantic and Mediterranean continental margins, Deep-Sea Res. I, 57, 441-457, 2010.

Rex, M. A., Etter, R. J., Morris, J. S., Crouse, J., McClain, C. R., Johnson, N. A., Stuart, C. T., Thies, R., and Avery, R.: Global bathymetric patterns of standing stock and body size in the deepsea benthos, Mar. Ecol. Progr. Ser. 317, 1-8, 2006.

Ruhl, H. A. and Smith, K. L.: Shifts in deep-sea community structure linked to climate and food supply, Science, 305, 513-515, 2004.

Ruhl, H. A., Ellena, J. A., and Smith, Jr., K. L.: Connections between climate, food limitation, and carbon cycling in abyssal sediment communities: a long time-series perspective, P. Natl. Acad. Sci. USA, 105, 17006-17011, 2008.

Sampéré, T. P., Bianchi, T. S., Wakeham, S. G., and Allison, M. A.: Sources of organic matter in surface sediments of the Louisiana Continental margin: effects of major depositional/transport pathways and Hurricane Ivan, Cont. Shelf Res., 28, 2472-2487, 2008.

Sanchez-García, L., de Andres, J. R., Martin-Rubi, J. A., and Louchouarn, P.: Diagenetic state and source characterization of marine sediments from the inner continental shelf of the Gulf of Cadiz (SW Spain), constrained by terrigenous biomarkers, Org. Geochem., 40, 184-194, 2009.

Sanchez-Vidal, A., Pasqual, C., Kerhervé, P., Calafat, A., Heussner, S., Palanques, A., Durrieu de Madron, X., Canals, M., and Puig, P.: Impact of dense shelf water cascading on the transfer of organic matter to the deep western Mediterranean basin, Geophys. Res. Let., 35, 1-5, 2008. 
Sanchez-Vidal, A., Pasqual, C., Kerhervé, P., Heussner, S., Calafat, A. Palanques, A., Durrieu de Madron, X., Canals, M., and Puig, P.: Across margin export of organic matter by cascading events traced by stable isotopes, northwestern Mediterranean Sea, Limnol. Oceanogr., 54, 1488-1500, 2009.

Smith, K. L., and Kaufmann, R. S.: Long-term discrepancy between food supply and demand in the deep-eastern North Pacific, Science, 284, 1174-1177, 1999.

Smith, C. R., De Leo, F. C., Bernardino, A. F., Sweetman, A. K., and Martinez Arbizu, P.: Abyssal food limitation, ecosystem structure and climate change, Trends Ecol. Evol, 23, 518-528, 2008.

Smith, K. L., Ruhl, H. A., Bett, B. J., Billett, D. S. M., Lampitt, R. S., and Kaufmann, R. S.: Climate, carbon cycling, and deepocean ecosystems, P. Natl. Acad. Sci., 106, 19211-19218, 2010.

Sun, M., Aller, R. C., and Lee, C.: Early diagenesis of chlorophyll a in Long Island Sound sediments: a measure of carbon flux and particle reworking, J. Mar. Res., 49, 279-401, 1991.

Thiel, H.: Benthos in upwelling regions. In: Boje R, Tomczak M (eds) Upwelling ecosystems. Springer-Verlag, Berlin, 124-138, 1978.

Tselepides, A., Polychronaki, T., Marrale, D., Akoumianaki, I., Dell'Anno, A., Pusceddu, A., and Danovaro, R.: Organic matter composition of the continental shelf and bathyal sediments of the Cretan Sea (NE Mediterranean), Prog. Oceanogr., 46, 311-344, 2000 .
Underwood, A. J.: Experiments in Ecology: Their logical design and interpolation using analysis of variance, Cambridge University Press, Cambridge, 1997.

van Oevelen, D., Soetaert, K., García Novoa, R., de Stigter, H., da Cunha, M., Pusceddu, A., and Danovaro, R.: Canyon conditions impact carbon flows in food webs of three sections of the Nazarè canyon, Deep-Sea Res. II, 58, 2461-2476, 2011.

van Oevelen, D., Soetaert, K., and Heip, C.: Carbon flows in the benthic food web of the Porcupine Abyssal Plain: The (un)importance of labile detritus in supporting microbial and faunal carbon demands, Limnol. Oceanogr., 57, 645-664, 2012.

Vitorino, J., Oliveira, A., Jouanneau, J. M., and Drago, T.: Winter dynamics on the northern Portuguese shelf. Part 1: physical processes, Prog. Oceanogr., 52, 29-153, 2002.

Wakeham, S. G. and Canuel, E. A.: Degradation and preservation of organic matter in marine sediments, in: The Handbook of Environmental Chemistry, edited by: Volkman, J. K., 295-321, 2006.

Weaver, P. E., Billett, D. M., Boetius, A., Danovaro, R., Freiwald, A., and Sibuet, M.: Hotspot ecosystem Research on Europe's Deep-Ocean Margins, Oceanography, 17, 132-143, 2004. 